\title{
Smartphone: Social Attitude and Healthy Lifestyle
}

\author{
Erwin Setyo Kriswanto \\ Faculty of Sport Sciences \\ Universitas Negeri Yogyakarta \\ Yogyakarta, Indonesia \\ erwin_sk@uny.ac.id \\ Ranintya Meikahani \\ Faculty of Sport Sciences \\ Universitas Negeri Yogyakarta \\ Yogyakarta, Indonesia \\ ranintya.m@uny.ac.id
}

\author{
Indah Prasetyawati Tri P.S \\ Faculty of Sport Sciences \\ Universitas Negeri Yogyakarta \\ Yogyakarta, Indonesia \\ indah_prasty@uny.ac.id \\ Fredericus Suharjana \\ Faculty of Sport Sciences \\ Universitas Negeri Yogyakarta \\ Yogyakarta, Indonesia \\ suharjana@uny.ac.id
}

\begin{abstract}
-concerns about social attitudes and healthy life behavior problems due to the increasing use of mobile phones are growing. Excessive use of mobile phones can affect the quality of health literature and social attitudes of people. Therefore, this study is to determine the effect of smartphones on social attitudes and healthy life on 165 students of sport Yogyakarta, Indonesia, in 2018. The research type is survey research. The type of data used is quantitative data. To find out the correlation between smartphone use, social attitudes, and healthy life behavior, the researchers performed regression method. The results of the regression analysis show that there is significant correlation between smartphone use with social attitudes and healthy life behavior. The smartphone use is related to social attitudes $(r=.385, p=.000)$ and healthy life behavior $(r=.384, p=.000)$. In conclusion, the results indicate that smartphone use affects social attitudes and healthy life behavior.
\end{abstract}

Keywords-smartphone, social attitudes, healthy life behavior, students.

\section{INTRODUCTION}

Currently, the use of smartphones not only as a means of communication but also, has its own charm of sophistication. Design, ease of use, operating system, and price are some of the criteria of users in choosing a smartphone [1], Smartphones have finally become a necessity or trend equated with a personal computer. This is because the smartphone has many functions and almost many people use it every day [2]

Smartphones, in addition to having many functions, also has features that attract users such as the camera, internet and social media, which is easily used by the community. The number of functions and features in a smartphone sometimes have a negative impact on students.

Almost every student has a smartphone; most students in Saudi Arabia use smartphones as regular phones, as computers with internet connections, and as digital cameras. They use smartphones to learn, especially to log in to the academic portal. The results showed that $91.69 \%$ of students had used smartphones to enter their academic portal. However, $60.89 \%$ of students never use smartphones as a blackboard, $66.01 \%$ of students never use smartphones as a means to take notes in classrooms, $66.89 \%$ of participants never use smartphones to record lecture classes and $54.49 \%$ of participants use smartphones to download classroom material. Research findings show that almost every student has a smartphone and is used for normal use. However, other research results indicate that students in Saudi Arabia do not fully use smartphones for learning purposes $[3,4]$. The other negative side of the impact of smartphones is that students are always checking repeatedly on their smartphone during learning, and this leads to disruption [5].

The disorder is a student's response to something, so it can make a person become dependent. Students are part of the age of adolescents who have a dependency on their smartphones. This is reinforced by the results of research that there is rapid growth in the community, especially in adolescents. This trend was followed by rapid growth in the use of social networking services on smartphones (SNS) [6]. This SNS service has also been used in academic institutions. This is reinforced by the results of research which states that academic institutions and faculties use online social networking (OSN) such as Facebook and linked fields to communicate with students, prospective students, and even deliver learning material. The survey conducted was to determine the impact of internet use on academic performance. The results show that there is a statistically significant negative relationship between the time spent by students on OSN and their academic performance. The time spent turned out to be greatly influenced by the attention span. The higher the attention span, the lower the time spent. This range of attention affects students' behavior [7].

The student's attention span on smartphones in women is higher than that of men. The results showed that women's addiction scale scores were significantly higher than men's. Addiction scale scores on smartphones were also positively correlated with levels of depression, anxiety levels, and sleep quality [8]. This is reinforced by a survey conducted by Secur Envoy who conducted a survey of 1,000 people in the UK. From the research, it can be concluded that the students of today are experiencing nomophobia; that is, feeling anxious and afraid when not with their cell phone. The survey results showed $66 \%$ of respondents admitted they could not live without their cell phone. This percentage is increasingly bloated in respondents aged 18 and 24 years. As many as $77 \%$ of respondents among this age group experienced nomophobia [9]. The time span used by students to use SSN 
was reinforced with the results of a study conducted on 894 students in Taiwan, which obtained only $1 \%$ results classified as addicts, $17.8 \%$ were in the standby group. About $80 \%$ of students use Facebook every day, and $10 \%$ spend more than 8 hours a day on Facebook [10]. The presence of disturbances in the level of depression, anxiety, and sleep quality, as well as a longer time in the use of smartphones, of course, will affect health behavior.

Among the students today are many who are interested in using smartphones in everyday activities, including FIK UNY students. Students can use smartphones to communicate, exist in cyberspace, and to help search for material during lectures. Based on the results of a survey of researchers in Health Education Lecture Prodi PGSD 2017, as many as 95\% of FIK UNY students have smartphones and has obtained data that the average student uses a smartphone for 12 hours in a day of 24 hours. It is also seen at the time of lectures, that almost every student using a smartphone at the time of presenting. UNY is also implementing an online system that enables students to access information via smartphone.

The phenomenon of smartphones has now become a lifestyle of students, which can unwittingly affect social attitudes and healthy living behavior. Excessive use of smartphones can cause irregular rest and social interaction directly between humans. Time to rest becomes reduced, so does the shift of regular meals and reduced social interaction with friends in the surrounding environment. Therefore, researchers want to explore deeply, the effect of smartphones on social attitudes and healthy life behavior.

\section{A. Smartphone}

The smartphone is an innovation of the latest technology with the latest capabilities and features that have purpose and function more practically and usefully. Smartphones are widely used by all circles of society. The existence of smartphones is now easier for humans in obtaining information through advanced phones owned by the user. In the past, humans used communication tools such as mobile phones, which can only be used for calls and SMS only. As science and technology advanced, mobile phones developed into smartphones that has certain attractions and features such as, cameras, applications, mp3 and others. Smartphones are also sophisticated and easy to carry anywhere. The emergence of internet in smartphones has brought a number of changes in everyday life. Past sources of information which could be obtained only through books can now all be sourced from the internet accessible via smartphone [11].

Technology has become an integral part of everyday society's life [12]. Some even say that the use of smartphone's technology in particular is an important part of life to maintain a productive lifestyle, intimate social interaction, and professional progress. Smartphones are used primarily for social or entertainment purposes. Several studies have reported that learners choose not to use their mobile devices in educational goals. From the above understanding, it can be concluded that with the existence of smartphones, technological advances are now giving attraction to the wider community. Smartphones have offered some advanced features that can make the user to not be away from it.

\section{B. Social Attitudes}

Humans are social beings who cannot be separated from social life. Humans interact with communication because every human needs the help of others with good interaction. Interaction between humans is always carried out every day, because social interaction is done with continuous social values that appear in life. Social interaction is a process that every human being undertakes in the life of society. A common example of social interaction in society is direct communication, cooperation and mutual cooperation. The main purpose of this process is to make changes in life to be better.

Humans are now living in an age of globalization that has affected the lives of people, even to the extent that they do not realize. This can affect social attitudes in society. There are several things that influence the formation and change of social attitudes. The formation of an attitude is much influenced by the social and cultural environment, such as family, school, norms, religious class, and customs [13]. Attitudes grow and flourish in certain social bases, such as economy, politics, religion, and so on. Attitudes in its development are much influenced by the environment, norms or groups. This results in differences in attitudes between individuals with each other due to differences in influence or environment received. The factors that led to the change in attitude were:

1. Internal factors: factors that exist in the human person itself. This factor is in the form of selectivity or a person's ability to receive and cultivate influences coming from outside which are usually adapted to the motives and attitudes within the human being, especially those of interest.

2. External factors: factors that exist outside the human person. This factor is a social interaction within and outside the group

The growing use of smartphones among teenagers, raises a variety of changes in attitudes and behavior among adolescents themselves. It has been claimed that mobile phones have become a part of our self-identity, in part due to the social interaction they enable and their uptake is starting at an early age [14]. Teenagers prefer to communicate with friends who are in a smartphone user community rather than communicating with friends around them. In $2010,82 \%$ of Australian adolescents above the age of 13 years were using a mobile phone [15]. Many people can find happy media between face-to-face interactions, talking on the phone, sending message, and connecting on social media sites. Some people can avoid the pitfalls involved in the use of everyday technology and use it socially, professionally and financially to benefit their lives.

Smartphone technology that satisfies the demand for comfort has many advantages and can even bring a more efficient lifestyle for its users [16]. Unfortunately, many individuals in the group recognize that they not only open their smartphones when they call or send messages, but continuously and repeatedly check whether there might be a message. They also fully realize that their Facebook newsfeed has not changed in the last 5 minutes, but they feel 
they have to check it over and over again. It has proved that there is a bad influence on social attitudes for users who have dependence on their owned smartphones. With users engrossed with smartphone sophistication, it will reduce the social interaction between a person and the environment.

\section{Healthy Life Behavior}

A healthy lifestyle is all the activities or activity of a person, both observable and unobservable, related to the maintenance and improvement of health. Healthy behavior in the home/residence is in essence, a positive action that is done as a person supported by a healthy and perfect condition both of the body and the environment, so as to build harmony between individual and environment in an effort to achieve healthy life balance with environment. Factors that affect healthy life behavior include the following [17]:

1. Food and beverage factors consisting of breakfast habits, selection of food, amount of food and drink, food hygiene.

2. Behavioral factors of personal hygiene consisting of bathing, cleaning the mouth and teeth, cleaning hands and feet, cleaning clothes.

3. Behavioral factors toward environmental hygiene consisting of room cleanliness, house hygiene, cleanliness of the home environment, cleanliness of the school environment.

4. Behavioral factors of illness and illness consisting of health care, disease prevention, treatment plan and health restoration.

5. The balance factor between rest and sports activities consisting of many rest periods, home activities, and regular exercise.

Someone who depends on a smartphone, will spend more time to explore interesting features on it than on physical activity. It is undeniable that the smartphone offers many features and can be used to access the internet at any time that now seems to be the main requirement of each user. However, without realizing the existence of excessive smartphone use, time of rest is exceeded and can cause irregular sleep patterns. Despite their popularity, mobile phones have long been purported to negatively influence adolescent sleep [18]. That is, problematic phone use was not associated with short sleep duration $(<6 \mathrm{hr})$ when other demographic and lifestyle factors, such as having selfreported depression, were considered [19]. Night time messaging was related to poor school performance and daytime sleepiness, after controlling for sleep duration, indicating that evening phone use impacts daytime functioning [20]. Adolescents who use the internet, social media, games with crude humour and violence, check emails, and/or watch videos on mobile devices, all of which can be performed from mobile phones, reported higher daytime sleepiness [21].

Physiologically irregular sleep patterns cause disruption of growth hormone secretion (Growth Hormone). GH is secreted about an hour after a deep sleep begins, this happens around 12-1 hours a night. If irregular sleep patterns are done continuously, it will affect the secretion of GH. GH secretion has a role in adjusting the levels of glucose, amino acids, and fatty acids in the blood. GH has a role in maintaining the balance of energy sources for the body (muscle and brain). The occurrence of deficiency or decrease in GH in adulthood after the growth is completed causes relatively few symptoms. Adults with reduced GH tend to decrease muscle mass and strength (less muscle protein) as well as decreased bone density (reduced osteoblast activity). In addition, because $\mathrm{GH}$ is important for maintaining mass and muscle performance in the heart during adulthood, GH deficiency in adults can lead to an increased risk of heart failure [22].

\section{METHOD}

\section{A. Participants}

A total 165 students were recruited as purposive random sampling from students in Yogyakarta.

TABLE I. The PARTICIANTS By Gender

\begin{tabular}{|c|c|c|c|}
\hline & Frequency & Percent & Valid percent \\
\hline Male & 110 & 66.7 & 66.7 \\
\hline Female & 55 & 33.3 & 33.3 \\
\hline Total & 165 & 100 & 100 \\
\hline
\end{tabular}

TABLE II. The PARTiciants By AgE

\begin{tabular}{|c|c|c|c|}
\hline Age & Frequency & Valid & Valid percent \\
\hline 19 & 70 & 42.4 & 42.4 \\
\hline 20 & 13 & 7.9 & 7.9 \\
\hline 21 & 82 & 49.7 & 49.7 \\
\hline Total & 165 & 100 & 100 \\
\hline
\end{tabular}

\section{B. Design of Research}

This type of research is a survey research. Survey research method is an investigation conducted to obtain facts from the symptoms that exist and look for deficiencies factually. The type of data used is quantitative data. This is data in the form of numbers. In accordance with its form, quantitative data can be processed or analyzed using mathematical calculation techniques or statistics.

\section{Instrument and Data Analysis Technique}

The data in this research is obtained by filling the questionnaire from the respondent. Instruments used in this study are in the form of a questionnaire. A questionnaire is a number of questions or statements used to obtain sample information in the sense of his personal report, or things he or she knows. Questionnaires in this study are presented in such a way that the respondent gives a check mark $(\sqrt{ })$ on the appropriate column or place, using the Likert Scale. Likert scale is used to measure attitudes, opinions, and perceptions of a person or group of people in social phenomena.

This research uses simple linear regression analysis technique, because the variables involved in this research include one independent variable and two dependent variables. Simple linear regression analysis can be performed 
if it meets the following requirements: samples taken randomly (randomly), variable $\mathrm{X}$ and variable $\mathrm{Y}$ have a causal relation, where $\mathrm{X}$ is cause and $\mathrm{Y}$ is a result, $\mathrm{Y}$ value has spread normally distributed, the equation should be completely linear.

\section{RESULTS}

\section{A. Normality Test}

Testing the normality of data distribution in this study using kolmogorov smirnov, the results of the calculation of data normality test in summary can be seen in the following table.

TABLE III. NORMALITY TEST

\begin{tabular}{|l|l|l|}
\hline \multicolumn{1}{|c|}{ Variable } & P-value & Explanation \\
\hline Smartphone use & 0.073 & Normal \\
\hline Healthy life behavior & 0.905 & Normal \\
\hline Social attitude & 0.705 & Normal \\
\hline
\end{tabular}

Based on the data normality test table above, note that the overall p-value $>0.005$. p-value of use of $\mathrm{Hp}$ by 0.073 ; health 0.905 ; social 0.705 . it can be concluded that the data in this study is normally distributed. Thus all the data in this study meet the assumptions of distribution normality.

\section{TABLE IV. LINIEARITY TEST}

\begin{tabular}{|c|c|c|c|}
\hline Functional Relationship & F-Value & P-Value & Explanation \\
\hline $\begin{array}{c}\text { Relationship between } \\
\text { smartphones and healthy } \\
\text { life behavior }\end{array}$ & 1.544 & 0.056 & Linear \\
\hline $\begin{array}{c}\text { Relationship between } \\
\text { smartphones and social } \\
\text { attitude }\end{array}$ & 1.101 & 0.348 & Linear \\
\hline
\end{tabular}

Explanation:

$\mathrm{F}$ value is $\mathrm{F}$ deviation from linearity, which means, if $\mathrm{p}>$ 0.05 means data is not deviant or linear.

Result of linearity test as a whole show p-value of healthy life behavior is 0.056 and social attitude is $0.348, p$ value both $>0.05$ which means it does not deviate from linearity. This means that there is a linear relationship and has fulfilled the prerequisite test so that the regression test can proceed.

\section{B. Hypothesis Test}

\section{Coefficient of Determination}

TABLE V. COEFFICIENT OF DETERMINATION

\begin{tabular}{|l|l|l|}
\hline \multicolumn{1}{|c|}{ Relationship } & R & R Square \\
\hline Smartphones with healthy life & $0.384 \mathrm{a}$ & 0.147 \\
\hline Smartphones with social attitude & $0.385 \mathrm{a}$ & 0.148 \\
\hline
\end{tabular}

The coefficient of determination (R2) of healthy life behavior is 0.147 , thus the effect of smartphone use on healthy life behavior is $14.7 \%$ while the rest is influenced by other variables outside the regression model. The coefficient of determination (R2) of social attitude is 0.148 , thus the effect of smartphone use on social attitude is $14.8 \%$ while the rest is influenced by other variables outside the regression model

TABLE VI. LinEAR REgRESSION (PARTIAL T TEST)

\begin{tabular}{l|l|l|c}
\hline Variable & t & P-value & Explanation \\
\hline Healthy life & 5.308 & 0.000 & Significant \\
\hline Social attitude & 5.320 & 0.000 & Significant \\
\hline
\end{tabular}

The result of $t$ test on the research data shows that the $p$ value of healthy life behavior is $0.000<0.005$, then there is a significant effect of smartphone usage on healthy life behavior. In social attitudes $p$ value of $0.000<0.05$, then there is a significant effect of smartphone use on social attitudes

TABLE VII. LINEAR REGRESSION F TEST

\begin{tabular}{|l|l|c|l|}
\hline Variabel & F & P-value & Explanation \\
\hline Healthy life & 28.172 & 0.000 & Normal \\
\hline Social attitude & 28.303 & 0.000 & Normal \\
\hline
\end{tabular}

The result of $\mathrm{F}$ test data analysis on healthy life behavior shows $F$ value 28.172 and $F$ calculates social attitude equal to 28.303 with level of significance / $\mathrm{p}$ value of the second variable equal to $0.000<0.05$, then regression model can be used to predict influence model.

TABLE VIII. REGRESSION EQUATION

\begin{tabular}{|l|l|l|l|}
\hline \multicolumn{1}{|c|}{ Model } & \multicolumn{2}{|c|}{$\begin{array}{l}\text { Unstandardized } \\
\text { Coefficients }\end{array}$} & $\begin{array}{l}\text { Standardized } \\
\text { Coefficients }\end{array}$ \\
\hline B & Std. Error & Beta \\
\hline (Constant) & 35.365 & 4.806 & 0.384 \\
\hline $\begin{array}{l}\text { Healthy life } \\
\text { behavior }\end{array}$ & 0.490 & 0.092 & \\
\hline (Constant) & 52.715 & 4.070 & 0.385 \\
\hline Social attitude & 0.416 & 0.072 & \\
\hline
\end{tabular}

Independent Variable: Smartphone usage 
Based on the results of regression analysis contained in table 6 , it can be seen that the form of relationship between the use of smartphone with healthy life behavior and the form of relationship between the use of smartphone with social attitudes can be described from the regression equation obtained with the formula $\mathrm{Y}=\mathrm{a}+\mathrm{bx}$. Regression equation of healthy life behavior that is $\mathrm{Y}=35.365+0.490 \mathrm{X}$; which means any increase in points on the use of smartphone by 1 point will be followed by a rise in healthy life behavior of 0.416 points at the constant 35.365 ; whereas the regression equation on social attitude was obtained $\mathrm{Y}=52.715+0.416$ $\mathrm{X}$; which means any increase in points on the use of smartphones by 1 point will be followed by a rise in social attitude results by 0.416 points at the constant 52.715 .

\section{DISCUSSION}

The results showed that there was a significant relationship between smartphones and social attitudes and healthy behavior. Based on these results it can be seen that the smartphone helps in finding information, both information relating to lecture material, assignments and health. In relation to social attitude, smartphones has a positive impact on daily life. The results showed that in communicating they were very concerned about the language used and with whom they were communicating. Other results indicate that while using a smartphone they still pay attention to healthy behavior, one of which is throwing trash in its place.

The results of this study also stated that respondents used smartphones more than 2 hours. On average in a day, respondents use a smartphone for 7 hours. The duration of smartphone use in women is longer than men. These results are consistent with the results of Nielsen On Device Meter (ODM) study in February 2014 regarding the behavior of women who tend to spend more time using smart phones than men. Women can spend 140 minutes per day, while men only spend 43 minutes a day. Other data shows that many respondents use smartphones in a recline position. This of course has a negative influence on health. These effects include tired eyes, cataracts, insomnia, body fatigue, worsening sleep quality, eye cancer, exposure to radiation, stress and blindness. The duration of using a smartphone in recline position will be very detrimental to health.

\section{CONCLUSION}

The results indicate that smartphone use affects social attitudes and healthy life behavior. On average in a day respondents use a smartphone for 7 hours. The duration of smartphone use in women is longer than men. Many respondents use smartphones in a recline position which has a negative influence on health. These effects include tired eyes, cataracts, insomnia, body fatigue, worsening sleep quality, eye cancer, exposure to radiation, stress and blindness. Using a smartphone in recline position is very detrimental to health.

\section{REFERENCES}

[1] Osman, M. Azam, et al. "A Study of the Trend of Smartphone and its Usage Behavior in Malaysia." International Journal of New Computer Architectures and their Applications (IJNCAA) 2.1 (2012): 274-285.

[2] Park, Bong-Won, and K. C. Lee. "The effect of users' characteristics and experiential factors on the compulsive usage of the smartphone." International Conference on Ubiquitous Computing and Multimedia Applications. Springer, Berlin, Heidelberg, 2011

[3] Alfawareh, M. Hejab and S. Jusoh. "Smartphones usage among university students: najran university case." International Journal of Academic Research 6.2, 2014.

[4] Kibona, Lusekelo, and G. Mgaya. "Smartphones' effects on academic performance of higher learning students." Journal of Multidisciplinary Engineering Science and Technology 2.4, 2015: 777-784.

[5] Oulasvirta, Antti, et al. "Habits make smartphone use more pervasive." Personal and Ubiquitous Computing 16.1 (2012): 105-114.

[6] Islam, Rashedul, R. Islam, and T. Mazumder. "Mobile application and its global impact." International Journal of Engineering \& Technology (IJEST) 10.6, 2010: 72-78.

[7] Paul, J. Aliyas, H. M. Baker, and J. D. Cochran. "Effect of online social networking on student academic performance." Computers in Human Behavior 28.6, 2012: 2117-2127.

[8] Demirci, Kadir, M. Akgönül, and A. Akpinar. "Relationship of smartphone use severity with sleep quality, depression, and anxiety in university students." Journal of behavioral addictions 4.2, 2015: 8592.

[9] M. Ngafifi. Kemajuan teknologi dan pola hidup manusia dalam perspektif sosial budaya. Jurnal Pembangunan Pendidikan: Fondasi dan Aplikasi, 2014. Volume 2, Nomor 1.

[10] Tang, Jih-Hsin, et al. "Personality traits, interpersonal relationships, online social support, and Facebook addiction." Telematics and Informatics 33.1 (2016): 102-108.

[11] G. Eason, B. Noble, and I. N. Sneddon, "On certain integrals of Lipschitz-Hankel type involving products of Bessel functions," Phil. Trans. Roy. Soc. London, vol. A247, pp. 529-551, April 1955. (references)

[12] Lundquist, A, "Smartphone: Fulfilling the need for immediacy in everyday life, but at what cost?", International Journal of Humanities and Social Science, 2014, vol. 4, pp.80-89.

[13] Ahmadi, "Psikologi sosial" Jakarta: Rineka Cipta, 2009.

[14] Vincent, J, "Emotional attachment and mobile phones. Knowledge, Technology \& Policy”, 2006, 19, pp. 39-44.

[15] Inyang, I., Benke, G., Dimitriadis, C., Simpson, P., McKenzie, R., \& Abramson, M. "Predictors of mobile telephone use and exposure analysis in Australian adolescents". Journal of Paediatrics and Child Health, 2010, 46, pp. 226-233.

[16] Y. Yorozu, M. Hirano, K. Oka, and Y. Tagawa, "Electron spectroscopy studies on magneto-optical media and plastic substrate interface,” IEEE Transl. J. Magn. Japan, vol. 2, pp. 740-741, August 1987 [Digests 9th Annual Conf. Magnetics Japan, p. 301, 1982].

[17] M. Young, The Technical Writer's Handbook. Mill Valley, CA: University Science, 1989.

[18] Adams, S. K., Daly, J. F., \& Williford, D. N. Adolescent sleep and cellular phone use: Recent trends and implications for research. Health Services Insights, 6, 99, 2013.

[19] Yen, C. F., Ko, C. H., Yen, J. Y., \& Cheng, C. P, "The multidimensional correlates associated with short nocturnal sleep duration and subjective insomnia among Taiwanese adolescents". Sleep, 2008, pp. 1515-1525.

[20] Wang, X. T., Yi, Z., Kang, V., Xue, B., Kang, N., Brewer, G., \& Ming, X, "Messaging affects sleep and school performance in Chinese adolescents". Health Behavior and Policy Review, 2017, 4, 60-66.

[21] Eggermont, S., \& Van Den Bulck, J, "Nodding off or switching off? The use of popular media as a sleep aid in secondary-school children. Journal of Paediatrics and Child Health", 2006, 42, 428-433.

[22] Lauralee Sherwood. Fisiologi manusia. Jakarta: Penerbit Buku Kedokteran ECG, 2013. 